\title{
Dissemination of cagA and cagE Virulence Genes Among $H$. Pylori Strains From Sudanese Patients With Gastric Discomfort
}

Esraa Osman ( $\sim$ zaytoona95hassan@gmail.com )

Sudan University of Science and Technology

Maram M. Elnosh

Sudan University of Science and Technology

Aalaa Mahgoub Albasha

Sudan University of Science and Technology

Amira A M Fadl

The National Ribat University

Luai Osman Ibrahim Marouf

Khartoum University

Hisham N. Altayb

King Abdulaziz University

Research note

Keywords: H. pylori, cagA, cagE, Sudan

Posted Date: May 26th, 2021

DOl: https://doi.org/10.21203/rs.3.rs-551198/v1

License: (1) This work is licensed under a Creative Commons Attribution 4.0 International License.

Read Full License 


\section{Abstract}

\section{Objectives}

Helicobacter pylori cytotoxin-associated gene pathogenicity island (cag-PAI) is one of the strain-specific genes (they do not exist in all strains). cag-PAl is involved in inducing inflammation, ulceration, and carcinogenesis. This study aimed to detect and characterize cagA and cagE virulence genes among $H$. pylori strains from Sudanese patients with gastric discomfort.

\section{Result}

Out of 288 gastric biopsies screened for the presence of $H$. pylori, 34\% (98/288) were positive, cagA gene was present in $41 \%$ (40/98) of specimens, mostly in patients with gastritis $72.5 \%$ (29/40), followed by duodenal ulcer $15 \%(6 / 40)$, esophagitis $5 \%(2 / 40)$, and $7.5 \%(3 / 40)$ in patients diagnosed normal by endoscopy. cagE gene was present in $39 \%$ (38/98) of specimens, the majority $73.7 \%(28 / 38)$ were from patients with gastritis, $10.5 \%$ (4/38) duodenal ulcer, 5.3\% (2/38) esophagitis, $2.6 \%$ (1/38) gastric ulcer, and $7.9 \%(3 / 38)$ were diagnosed as normal. The cagA and cagE protein sequences have synonymous amino acid variations.

\section{Introduction}

Helicobacter pylori (H. pylori) is a gram-negative bacterium, grows in a microaerophilic environment at $37^{\circ} \mathrm{C}$. It is one of the causative agents of gastric diseases [1], like chronic gastritis, ulcers (duodenal or gastric), gastric adenocarcinoma, and gastric mucosa-associated lymphoid tissue (MALT) lymphoma [2]. Previous studies showed that soil, water, animal manure, and human stool are the primary resources for H. pylori [3]. There is an opportunity for transmission from person to person [4]. Some factors affect the incidence of $H$. pylori infection; race, gender, social and socioeconomic status of the population [5].

The pathogenicity of $H$. pylori infection is mediated by environmental, bacterial virulence factors, and internal interaction with the host [6].

The virulence genes of $\mathrm{H}$. pylori are classified into 3 categories; strain-specific genes, phase variable genes, and genes with variable genotypes or structures depending on the strain [7]. Cytotoxin-associated gene pathogenicity island (cag-PAl) and plasticity island genes are strain-specific genes, and they do not exist in all strains [7].

The cag-PAl is a DNA fragment that contains 31 genes, including; cagA and cagE in addition to other genes [8]. cag-PAl genes involved in inducing inflammation, ulceration, and carcinogenesis [3]. The presence of cag-PAl is strongly associated with the outcomes of H. pylori infection [9].

The cagA protein behaves as a bacterial oncoprotein, affects the expression of vital proteins or its function in oncogenic or tumor suppressor signaling pathways [10]. 
The cagE gene encodes a secretory protein that induces secretion of IL-8 from infected epithelial cells; also this gene is important for translocation and phosphorylation of the cagA protein, some studies have suggested that it is a more accurate marker of an intact pathogenicity island and can be used with cagA as a marker for cag-PAI [11, 12, 13].

To date there are limited published studies about the detection and characterization of cagA and cag $\mathrm{E}$ genes of $\mathrm{H}$. pylori in Sudan, this information is of great importance in determining the virulence and clinical outcomes of $H$. pylori strains. Thus, this study was conducted to detect and characterize cagA and cagE genes of $H$. pylori strains from gastric biopsies of patients with gastric discomfort in Khartoum State.

\section{Materials And Methods}

This was a descriptive cross-sectional study conducted during the period from August 2018 to October 2019. The sampling technique was convenience (Non-probability).

\section{Collection of clinical specimens}

A total of 288 gastric biopsies were collected by gastric endoscope by the gastroenterologist in different Khartoum hospitals: Omdurman Medical Military Hospital, Police Hospital, Al-Buqa'a Specialized Hospital, Ibn Sina Hospital, and Fedail Hospital. The specimens were collected from patients suffering from gastric discomfort and indicated for endoscopy, in which both antrum and corpus were sampled. The specimens were collected using endoscopes, using $1.0 \mathrm{ml}$ brain heart infusion broth with $15 \%$ glycerol as transport media.

\section{DNA extraction and polymerase chain reaction (PCR)}

DNA was extracted using the guanidine chloride extraction method [14]. The extracted DNA was stored at $-70^{\circ} \mathrm{C}$ until use.

The PCR was performed using a thermocycler (Convergys, Germany) and specific primer (Table 1) according to the following protocols:

For glmM gene: initial activation at $94^{\circ} \mathrm{C}$ for 3 minutes, followed by 35 cycles at $94^{\circ} \mathrm{C}$ for 30 seconds, $58^{\circ} \mathrm{C}$ for 30 seconds, and $72^{\circ} \mathrm{C}$ for 30 seconds, then a final extension at $72^{\circ} \mathrm{C}$ for 3 minutes [15].

For $16 \mathrm{~S}$ rRNA gene: initial activation at $94^{\circ} \mathrm{C}$ for 3 minutes, followed by 35 cycles at $94^{\circ} \mathrm{C}$ for 30 seconds, $53^{\circ} \mathrm{C}$ for 30 seconds, and $72^{\circ} \mathrm{C}$ for 45 seconds, then a final extension at $72^{\circ} \mathrm{C}$ for 5 minutes [16].

For cagA gene: initial activation at $94^{\circ} \mathrm{C}$ for 3 minutes, followed by 35 cycles at $94^{\circ} \mathrm{C}$ for 30 seconds, $53^{\circ} \mathrm{C}$ for 30 seconds, and $72^{\circ} \mathrm{C}$ for 45 seconds, then a final extension at $72^{\circ} \mathrm{C}$ for 5 minutes [15].

For cagE genes: initial activation at $94^{\circ} \mathrm{C}$ for 3 minutes, followed by 35 cycles at $94^{\circ} \mathrm{C}$ for 30 seconds, $53^{\circ} \mathrm{C}$ for 30 seconds, and $72^{\circ} \mathrm{C}$ for 45 seconds, then a final extension at $72^{\circ} \mathrm{C}$ for 5 minutes [17]. 
Table (1): Sequences of primers used for the detection of H. pylori 16S rRNA, g/mM, cagA, and cagE genes.

\begin{tabular}{|c|c|c|c|}
\hline Gene & Primer sequence (from 5'-3') & $\begin{array}{l}\text { Size of PCR product (base } \\
\text { pairs) }\end{array}$ & References \\
\hline \multirow{2}{*}{$\begin{array}{l}\text { 16S } \\
\text { rRNA }\end{array}$} & F: GCTAAGAGATCAGCCTATGTCC & \multirow[t]{2}{*}{$532 b p$} & \multirow[t]{2}{*}{ [16] } \\
\hline & R: TGGCAATCAGCGTCAGGTAAT G & & \\
\hline \multirow[t]{2}{*}{$g / m \mathrm{M}$} & $\begin{array}{l}\text { F : } \\
\text { GGATAAGCTTTTAGGGGTGTTAGGGG }\end{array}$ & \multirow[t]{2}{*}{ 294bp } & \multirow[t]{2}{*}{ [15] } \\
\hline & R :GCTTACTTTCTAACACTAACGCGC & & \\
\hline \multirow[t]{2}{*}{$\operatorname{cagA}$} & $\begin{array}{l}\text { F: } \\
\text { ATAATGCTAAATTAGACAACTTGAGCGA }\end{array}$ & \multirow[t]{2}{*}{$128 b p$} & \multirow[t]{2}{*}{ [15] } \\
\hline & R: AGAAACAAAAGCAATACGATCATTC & & \\
\hline \multirow[t]{2}{*}{ cagE } & $\begin{array}{l}\text { F: } \\
\text { TTGAAAACTTCAAGGATAGGATAGAGC }\end{array}$ & \multirow[t]{2}{*}{$508 b p$} & \multirow[t]{2}{*}{ [17] } \\
\hline & R: GCCTAGCGTAATATCACCATTACCC & & \\
\hline
\end{tabular}

\section{DNA sequencing}

A total of 21 cagE and 5 cagA amplified gene products were sequenced by BGI Company in China. The BLAST program was used to align the nucleotide sequences with the reference sequences from GenBank. The nucleotide sequences of $\operatorname{cagA}$ and $\operatorname{cag}$ E genes were translated into their corresponding amino acid using ExPASY available online at https://web.expasy.org/translate/. BioEdit software was used to compare the translated amino acid sequences with four reference sequences (JF798705.1 and MK074991.1 for cagA, and AB191082.1 and AY153111.1 for cagE).

The cagE nucleotide sequences have been deposited in Genbank. The cagA sequences were shorter than $200 \mathrm{bp}$ so it was not accepted in Genbank.

\section{Statistical Analysis}

Data were analyzed using the Statistical Package for Social Science (SPSSversion11.5) computer program. Frequencies were calculated, the Chi-square test was used to test the association between variables, $p$-value $\leq 0.05$ was considered significant.

\section{Results}

\section{Gender and age groups}


Out of 288 patients, there were 160 (56\%) males and 128 (44\%) females; they have been divided into two age groups; 10 adolescents ( 2 males and 4 females) and 278 adults (158 males and 124 females).

\section{Clinical diagnosis}

Based on the gastroscopy findings; 188 (65.3\%) of the patients had gastritis, $25(8.7 \%)$ had a duodenal ulcer, 29 (10.1\%) had a gastric ulcer, 15 (5.2\%) had esophagitis, $1(0.3 \%)$ had MALTL, $1(0.3 \%)$ had duodenitis, and 29 (10.1\%) had normal gastric mucosa.

\section{Genotyping of H. pylori}

Out of 288 samples, 98 (34\%) were positive for H. pylori ( $\mathrm{g} / \mathrm{mM}$ and/or 16S rRNA positive), 88 (31\%) were 16S rRNA gene-positive and 42 (15\%) were glmM gene-positive, 32 (33\%) were positive for both genes (Figure 1). 50/98 (51\%) of the H. pylori-positive patients were females and 48/98 (49\%) were males. The majority of the $H$. pylori-positive patients were adults $95 / 98$ (97\%), and 3/98 (3\%) were adolescents.

\section{Cytotoxin associated genes (cagA and cagE)}

cagA gene was present in 40/98 (41\%) specimens, their clinical diagnosis as follows: 29 (72.5\%) gastritis, $6(15 \%)$ duodenal ulcer, 2 (5\%) esophagitis, and $3(7.5 \%)$ were diagnosed as normal by endoscopy. cagE gene was present in 38/98 (39\%) of the specimens, their clinical diagnosis as follows: 28 (73.7\%) gastritis, 1 (2.6\%) gastric ulcer, 4 (10.5\%) duodenal ulcer, 2 (5.3\%) esophagitis and 3 (7.9\%) were diagnosed as normal (Figure 2).

From H. pylori-positive specimens (98); 27/98 (28\%) were positive for both cagA and cagE genes, 13 specimens (13\%) were positive for cagA gene only, 11/98 (11\%) were positive for cagE gene only, 47/98 $(48 \%)$ were negative for both genes.

There was no statistically significant association between the presence of cagA and cagE virulence genes and clinical diagnosis ( $p$-value $=0.305)$.

\section{DNA sequencing}

The comparison of 5 cagA protein sequences with the JF798705.1 reference from GenBank revealed substitution of proline $(P)$ with alanine (A), with 100\% identity to MK074991.1 reference sequence (Figure $3)$.

The comparison of 21 cagE protein sequences with the AY153111.1 reference sequence from GenBank, revealed a substitution mutation in one sequence, the sequence has valine $(V)$ instead of isoleucine $(I)$, with $100 \%$ identity to AB191082.1 reference sequence (Figure S1 and Figure S2).

\section{Discussion}


In the present study, out of 288 gastric biopsies, 98 (34\%) were positive for $H$. pylori, using PCR targeting 16S rRNA and g/mM genes. These genes are more sensitive than other genes in detecting $H$. pylori infection from gastric biopsies [18]. So, we have used them for the detection of $H$. pylori in biopsy samples.

H. pylori infection prevalence was $79.1 \%$ in Africa, $54.7 \%$ in Asia, and $37.1 \%$ in Northern America [19]. The geographic variation in the prevalence may be due to the uneven distribution of $\mathrm{H}$. pylori in the stomach in the different clinical settings, gender, race, social and socioeconomic status of the population $[5,20]$.

In Sudan, there is scanty information about the prevalence of H. pylori infection [14]. The prevalence in this study may indicate a low rate of $H$. pylori infection. Most of the previous studies investigating $H$. pylori seroprevalence using tests for the detection of $H$. pylori lgM and IgG antibodies. They reported a seroprevalence ranging from $20 \%$ up to $70 \%$ [21]. While PCR was used in this study which has significantly higher accuracy than stool antigen test and antibody-based tests used in the mentioned Sudanese studies.

In this study $50 / 98(51 \%)$ of the infected patients were females, this may attributed to the possibility of transmission from animal and their products, as women may deal with foods with animal origins when preparing food. This result in contrasts with other reports, noting a high existence of infection among males [22]. The majority of the infected patients were adults $96 / 98$ (98\%), the infected adolescents were $2 / 98(2 \%)$, this result is in harmony with El-Shenawy [23] and Salih [24] studies, they mentioned that; the prevalence of $H$. pylori infection increases with age.

cagA in this study was detected in $41 \%$ (40/98) of specimens, with high frequency in patients with gastritis (72.5\%). The cagA prevalence in the present study is similar to that obtained in Nigeria (40\%), Cyprus (42.5\%), Bahrain and Jordan (25-60\%), and Iran (44-94\%), and it is lower than results obtained from other countries including; Egypt (65.2\%), Palestine (65.9\%), Tunisia (61.6\%), Russia (85\%), and India $(60 \%$ to $80 \%)[15,27]$. These data indicate that various parts of the world have different cagA prevalence.

cagE in this study was present in 39\% (38/98) of specimens, with high frequency in patients with gastritis (73.7\%). The presence of this gene was also varied geographically; in Turkey (28\%), Brazil (53.2\%), Malaysia (70\%), Thailand (88\%), India (77\%), the United States of America (64\%), and the United Kingdom (71\%) [27].

In the present study, the cagA gene was more frequent than $\operatorname{cag} \mathrm{E}$, and this result in agreement with Lima [28] study in which $28 \%$ of specimens were positive for both genes (cagA and cagE), which might be attributed to the importance of cagE for cagA translocation, as mention in Yong [10] study.

There was no statistically significant association between the presence of these virulence genes and the clinical outcomes in this study. This result is similar to Moaddeb [29] study, which found that; there is no significant association between cagA-positive strains and gastroduodenal diseases. In contrast with 
Yong [10] and Skoog [9] studies, they mentioned that the presence of cag-PAl is strongly associated with the outcomes of $H$. pylori infection.

The differences in H. pylori virulence may be attributed to geographic variations in the strain-specific (non-conserved) genes and reduced virulence of African H. pylori strains, as in Bullock [30] study, who also mentioned that cagA proteins produced by East Asian strains cause more extensive alterations in gastric epithelial cells than that produced by strains from other parts of the world.

The analysis of 5 cagA protein sequences in this study revealed a substitution mutation in two cagA protein sequences. This variation may be due to the high level of geographic variability in $H$. pylori protein sequences, which may lead to differences in H. pylori virulence. The comparison of $21 \mathrm{cag}$ E protein sequences in this study revealed a substitution mutation in one cagE protein sequence. This variation was synonymous according to Hamad's [27] study. Bullock [30] study mentioned that there is a high level of geographic variation in sequences of $H$. pylori proteins.

\section{Conclusion}

H. pylori low prevalence in this study (34\%) indicates that Sudan is in the low-risk region for infection. There is high dissemination of cagA and cagE genes in H. pylori from Sudanese patients. Still, they may have reduced virulence. The cagA and $c a g E$ protein sequences have synonymous amino acid variations.

\section{Limitations}

- DNA sequencing is not done to all specimens.

- Using of short cagA primers (128bp) for DNA sequencing.

\section{Abbreviations}

GC: gastric cancer.

cag-PAl: cytotoxin-associated gene pathogenicity island.

cagA: cytotoxin associated gene A.

cagE: cytotoxin associated gene $\mathrm{E}$.

T4SS: type IV secretion system.

SPSS: Statistical Package for Social Science.

\section{Declarations}

Ethical approval and consent to participate 
The research was approved by the Khartoum state Ministry of health research department on 1/3/2018. Written consent was obtained from patients.

\section{Availability of data and materials}

The cagE DNA sequences data were uploaded to the NCBI database under accession numbers; (MN418976, MN418977, MN418978, MN418979, MN418980, MN418981, MN418982, MN418983, MN418984, MN418985, MN418986, MN418987,MN418988, MN418989,MN418990, MN418991,MN418992, MN418993, MN418994, MN418995, and MN418996). Other data are available at: http://doi.org/10.6084/m9.figshare.13620422.

\section{Funding}

This study was funded by TWAS research grant No: 17-516 RG/BIO/AF/AC_G-FR3240297732.

\section{Acknowledgment}

Not applicable.

\section{Consent for publication}

Not applicable.

\section{Competing interests}

The authors declare that they have no competing interests.

\section{Author s' contributions}

MMM, HNA, EHO, AMA, and LOM designed the study. EHO, MMM, and AMA performed the experience. EHO, HNA, and LOM analyzed the data. EHO wrote the manuscript. All authors read and approved the final manuscript.

\section{References}

1. Shetty V, Ballal M, Lingadakai R, Mukhopadhyay A. Determination of Helicobacter pylori Virulence Genes in Clinical Isolates of Symptomatic Patients from South Coastal Region of Karnataka - A Preliminary Work. Austin Journal of Gastroenterol 2015; 2(1): 1031.

2. Arslan Z, Yılmaz O, Demiray-Gürbüz, E. Importance of antimicrobial susceptibility testing for the management of eradication in Helicobacter pylori World Journal of Gastroenterology. 2017; 23(16):2854-2869.

3. Yahaghi E, Khamesipour F, Mashayekhi F, Dehkordi F-S, Sakhaei M-H, Masoudimanesh M, Khameneie MK. Helicobacter pylori in Vegetables and Salads: Genotyping and Antimicrobial 
Resistance Properties. BioMed Research International. 2014; 11.

4. Momtaz H, Dabiri H, Souod N, Gholami M. Study of Helicobacter pylori genotype status in cows, sheep, goats and human beings. BMC Gastroenterology. 2014; 14(1):61.

5. Yılmaz N, KorukÖzer M. The Prevalence of Helicobacter Pylori babA, homB, aspA, and sabA Genes and Its Relationship with Clinical Outcomes in Turkey. Canadian Journal of Gastroenterology and Hepatology. 2019.

6. Šterbenc A, Jarce E, Poljak M, Homan M. Helicobacter pylori virulance genes. World Journal of Gastroenterology. 2019; 25:4810-4884.

7. Souod N, Sarshar M, Dabiri H, Momtaz H, Kargar M, Mohammadzadeh A, Abdi S. The study of the oipA and dupA genes in Helicobacter pylori strains and their relationship with different gastroduodenal diseases. Gastroenterology and Hepatology From Bed to Bench. 2015; 8(1):S47-S53.

8. Lima V-P, de-Lima M-A-P, Ferreira M-V-P, Barros M-A-B, Rabenhorst S-H-B. The relationship between Helicobacter pylori genes cagE and virB11and gastric cancer. International Journal of Infectious Diseases. 2010; 14:e613-e617.

9. Skoog E-C, Morikis V-A, Martin M-E, Foster G-A, Cai L-P, Hansen L-M, Li B, Gaddy J-A, Simon S-I, Solnick J-V. CagY-dependent regulation of type IV secretion in Helicobacter pylori is associated with alterations in integrin binding. MBio. 2018; 9(3):e00717-18.

10. Yong X, Tang B, Li B-S, Xie R, Hu C-J, Luo G, Qin Y, Dong H, Yang S- Helicobacter pylori virulence factor CagA promotes tumorigenesis of gastric cancer via multiple signaling pathways. Cell Communication and Signaling. 2015; 13(1):30.

11. da Costa D-M, dos Santos Pereira E, Rabenhorst S-H-B. What exists beyond cagA and vacA? Helicobacter pylori genes in gastric diseases. World journal of gastroenterology: World Journal of Gastroenterology. 2015; 21(37):10563.

12. Dabiri H, Maleknejad P, Yamaoka Y, Feizabadi M-M, Jafari F, Rezadehbashi M, Nakhjavani F-A, Mirsalehian A,Zali M-Distribution of Helicobacter pyloricagA, cagE, oipA and vacA in different major ethnic groups in Tehran, Iran. Journal of Gastroenterology and Hepatology. 2009; 24(8):1380-1386.

13. Ramis I-B, Vianna J-S, Silva Junior L-V-D, Groll A-V,Silva P-E-A- cagE as a biomarker of the pathogenicity of Helicobacter pylori.Revista da SociedadeBrasileira de Medicina Tropical. 2013; 46(2):185-189.

14. Aba Al Rahem SA, Elhag WI. Molecular Detection of Helicobacter pylori in Drinking Water in Khartoum State (Sudan). African Journal of Medical Sciences. 2018; 3(5).

15. Smith S-I, Fowora M-A, Lesi O-A, Agbebaku E, Odeigah P, Abdulkareem F-B, Onyekwere C-A, Agomo CA, Contreras M. Application of stool-PCR for the diagnosis of Helicobacter pylori from stool in Nigeria-a pilot study. Springerplus. 2012; 1(1):78.

16. Ye, F. The role of DNA supercoiling in the coordinated regulation of gene expression in Helicobacter pylori.

17. Lima VP, Silva-Fernandes IJDL, Alves MKS, Rabenhorst SHV. Prevalence of Helicobacter pylori genotypes (vacA, cagA, cagE and virB11) in gastric cancer in Brazilian's patients: An 
association with histopathological The International Journal of Cancer Epidemiology, Detection, and Prevention. 2011; 35:e32-e37.

18. Bibi F, Alvi SA, Sawan SA, Yasir M, Sawan A, Jiman-Fatani AA, Azhar El. Detection and Genotyping of Helicobacter pylori among Gastric ulcer and Cancer Patients from Saudi Arabia. Pakistan Journal of Medical Sciences. 2017; 33(2):320-324.

19. Sjomina O, Pavlova J, Niv Y,Leja M. Epidemiology of Helicobacter pylori Helicobacter, 2018; 23 : e12514.

20. Wang YK, Kuo FC, Liu CJ, Wu MC, Shih HY, Wang SS, Wu JY, Kuo CH, Huang YK, Wu UD. Diagnosis of Helicobacter pylori infection: Current options and developments. World Journal of Gastroenterology. 2015; 21(40): 11221-11235.

21. Mohamed AK, Elhassan NM, Awhag ZA, Ali FS, Ali ET, Mhmoud NA, Siddig EE, Hassan R, Ahmed ES, Fattahi A, Ahmed A. Prevalence of Helicobacter Pylori Among Sudanese Patients Diagnosed with Colon Polyps and Colon Cancer using Immunohistochemistry BMC Research Notes. 2020;13

22. Osman, N.A., Ahmed, A.A., Ahmed, M. and Osman, T. Seroprevalence of Helicobacter pylori among Sudanese Gastritis Patients. African Journal of Medical Sciences, 2016; 1(6).

23. El-Shenawy A, Diab M, Shemis M, El-Ghannam M, Salem D, Abdelnasser M, Shahin M, Abdel-Hady M, El-Sherbini E, Saber M. Detection of Helicobacter pylorivacA, cagA and iceA1 virulence genes associated with gastric diseases in Egyptian patients. Egyptian Journal of Medical Human Genetics. 2017; 18(4):365-371.

24. Salih KMA, Elfaki OA, Hamid YHM, Eldouch WMA, Diab M, Abdelgadir SO. Prevalence of Helicobacter pylori among Sudanese children admitted to specialized children hospital. Sudanese Journal of Paediatr. 2017; 17(1):14-18.

25. Sarma A, Hazarika BB, Patgiri SJ, Saikia L, Begum S, Hussain ME. Isolation of Helicobacter pylori from Gastric Biopsy Specimens and Evaluation of Common Contaminants Associated with Pylori Cultures. International Journal of Medical Research Professionals. 2016; 2(2):pp.161-164.

26. Leszczyńska K, Namiot A, Namiot Z, Leszczyńska JK, Jakoniuk P, Chilewicz M, Namiot DB, Kemona A, Milewski R, Bucki R. Patient factors affecting culture of Helicobacter pylori isolated from gastric mucosal specimens. Advances in Medical Sciences. 2010; 55(2):161-166.

27. Hamad AL, Shamran HA, Al-Maliki JM, Mahmood IA. Molecular Characteristics and Clinical Relevance of Cytotoxin-Associated Genes A and E of Helicobacter pylori from Patients with Gastric Diseases. Medical Journal of Babylon. 2019; 16(2):156-162.

28. Lima V.P, de-Lima MAP, Ferreira MVP, Barros MAB, Rabenhorst SHB. The relationship between Helicobacter pylori genes cagE and virB11 and gastric cancer. International Journal of Infectious Diseases. 2010; 14:e613-e617.

29. Moaddeb A, Fattahi MR, Firouzi R, Derakhshandeh A, Farshad S. Genotyping of the Helicobacter pylori cagA gene isolated from gastric biopsies in Shiraz, Southern Iran: a PCR-RFLP and sequence analysis approach. Jundishapur journal of microbiology. 2016; 9(4). 
30. Bullock KK, Shaffer CL, Brooks AW, Secka O, Forsyth MH, McClain MS, Cover TL. Genetic signatures for Helicobacter pylori strains of West African origin. PloS one. 2017; 12(11):e0188804.

\section{Figures}

$\mathbf{A}$

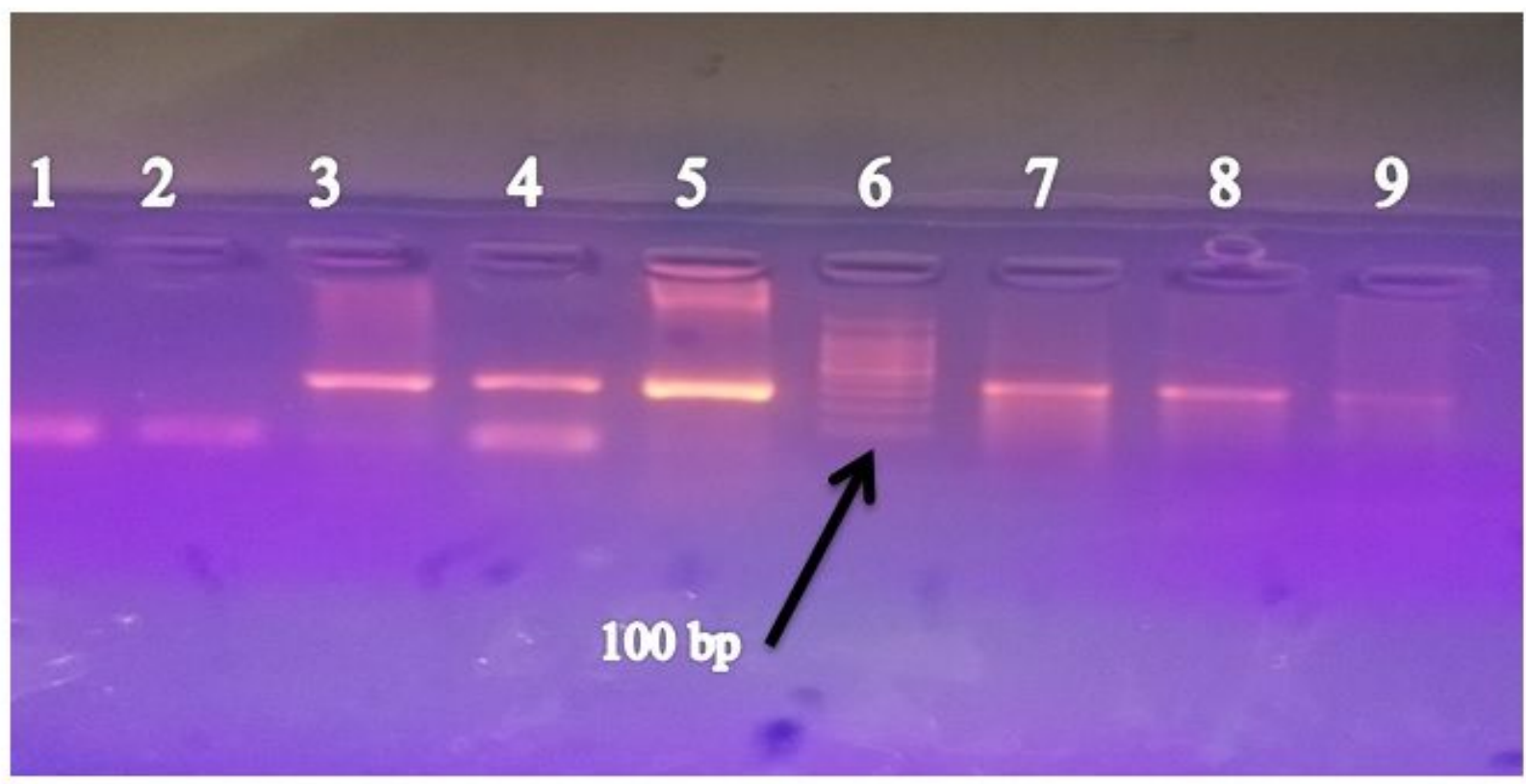

B

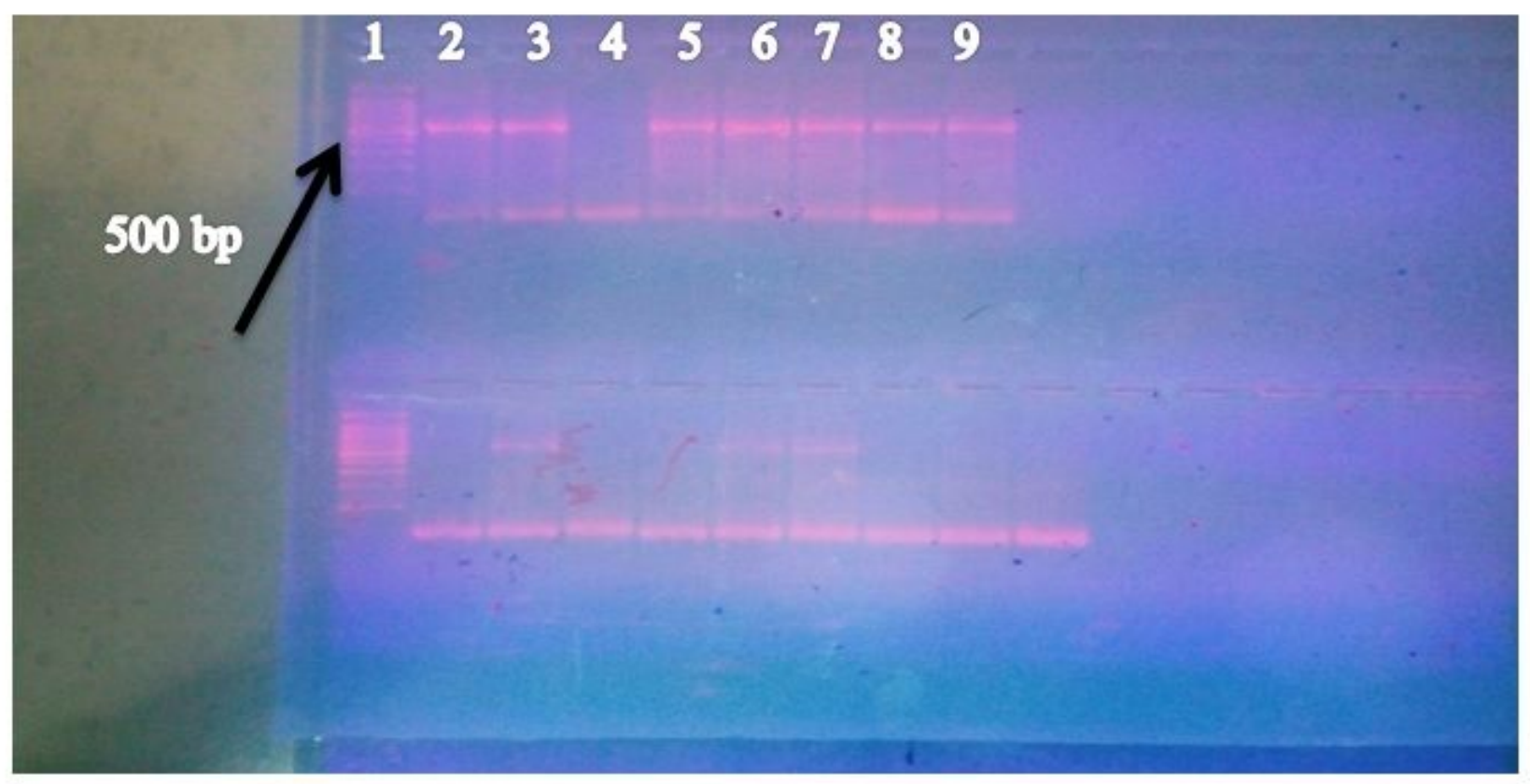

Figure 1 
Amplified DNA of the glmM gene (A) (Lanes 7, 8\& 9 contain gene does not included in this manuscript) and $16 \mathrm{~S}$ rRNA gene (B) on 1.5\% agarose gel electrophoresis.

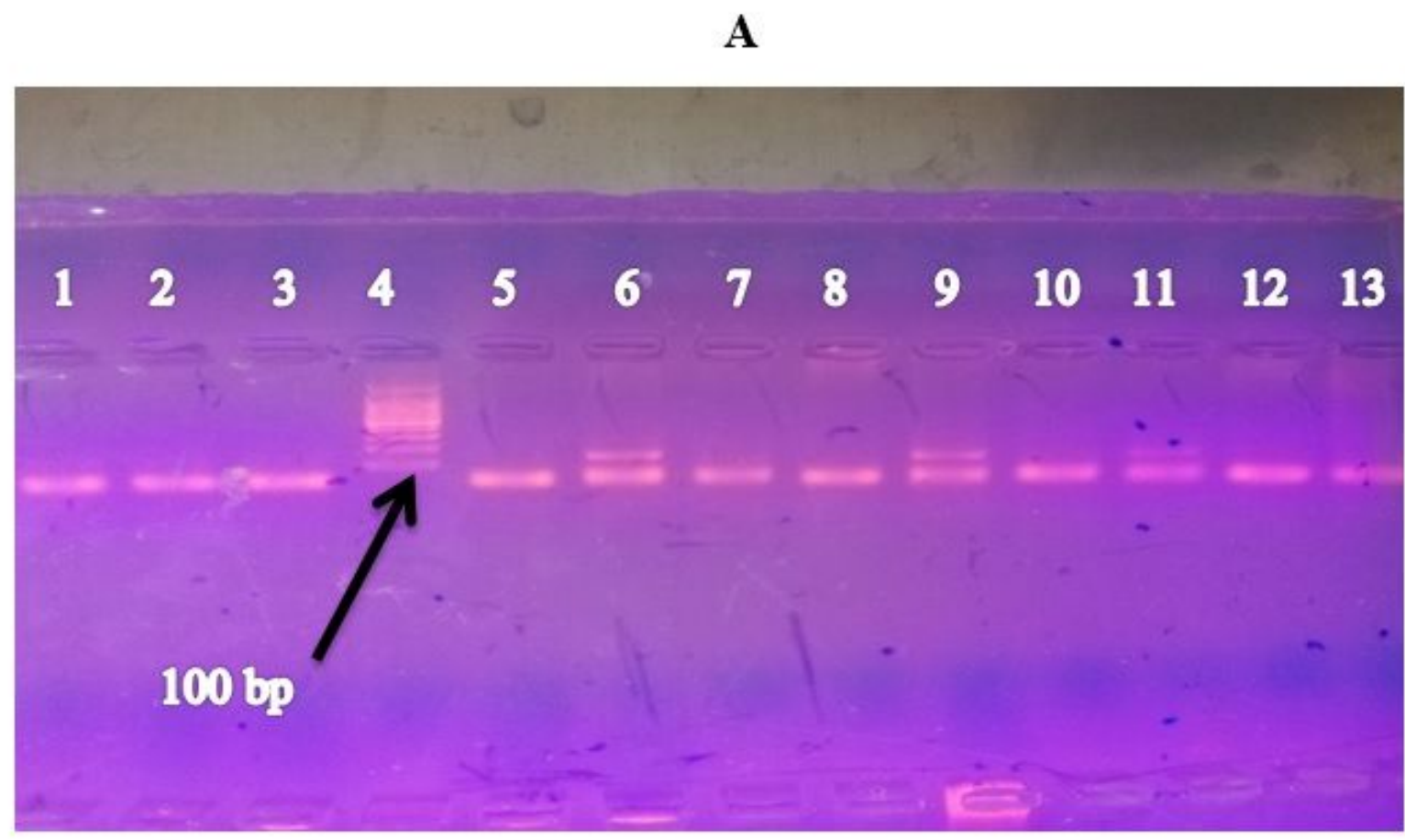

B

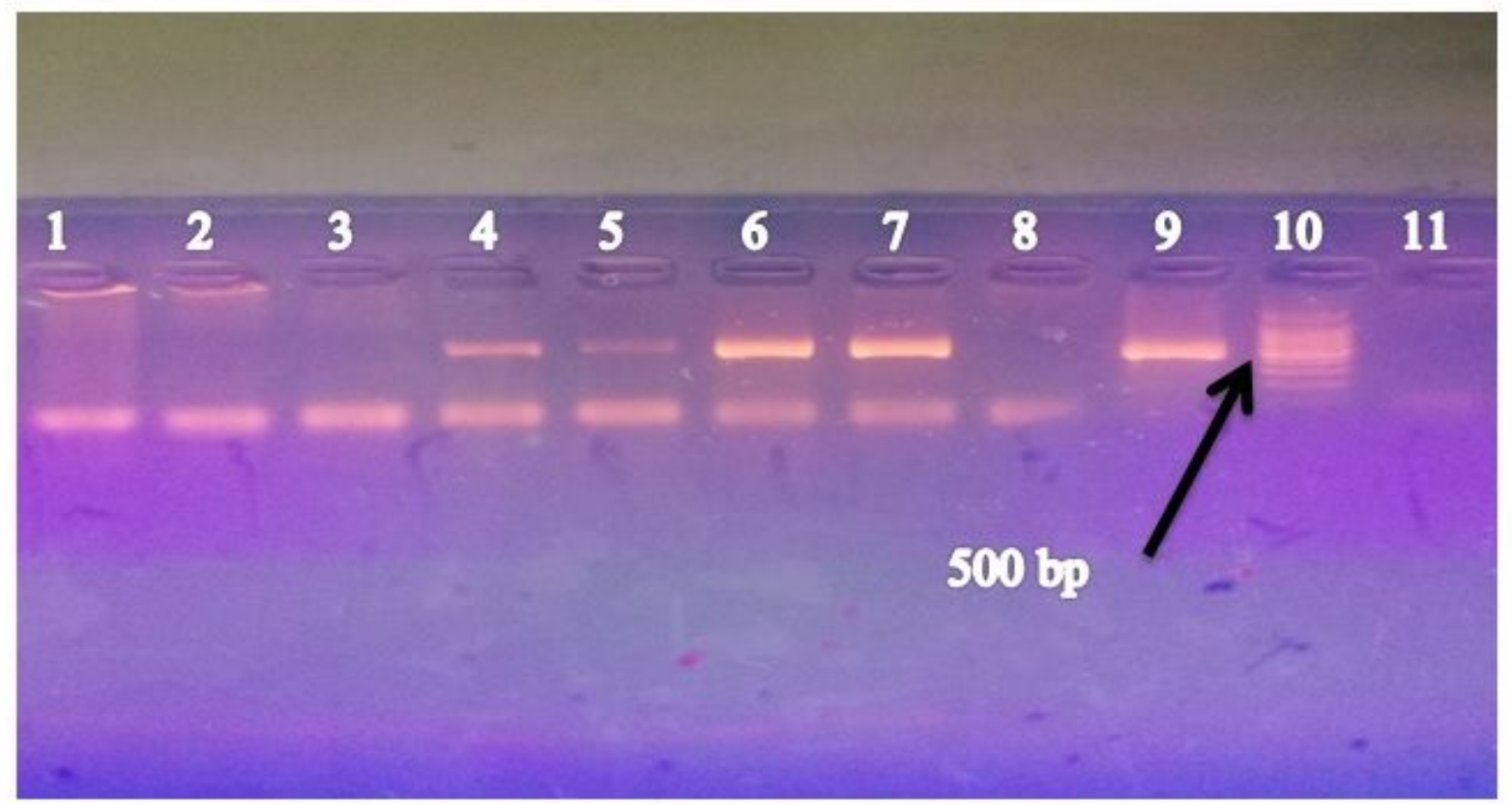

Figure 2

Amplified DNA of the cagA gene (A) and cagE gene (B) on 1.5\% agarose gel electrophoresis. 


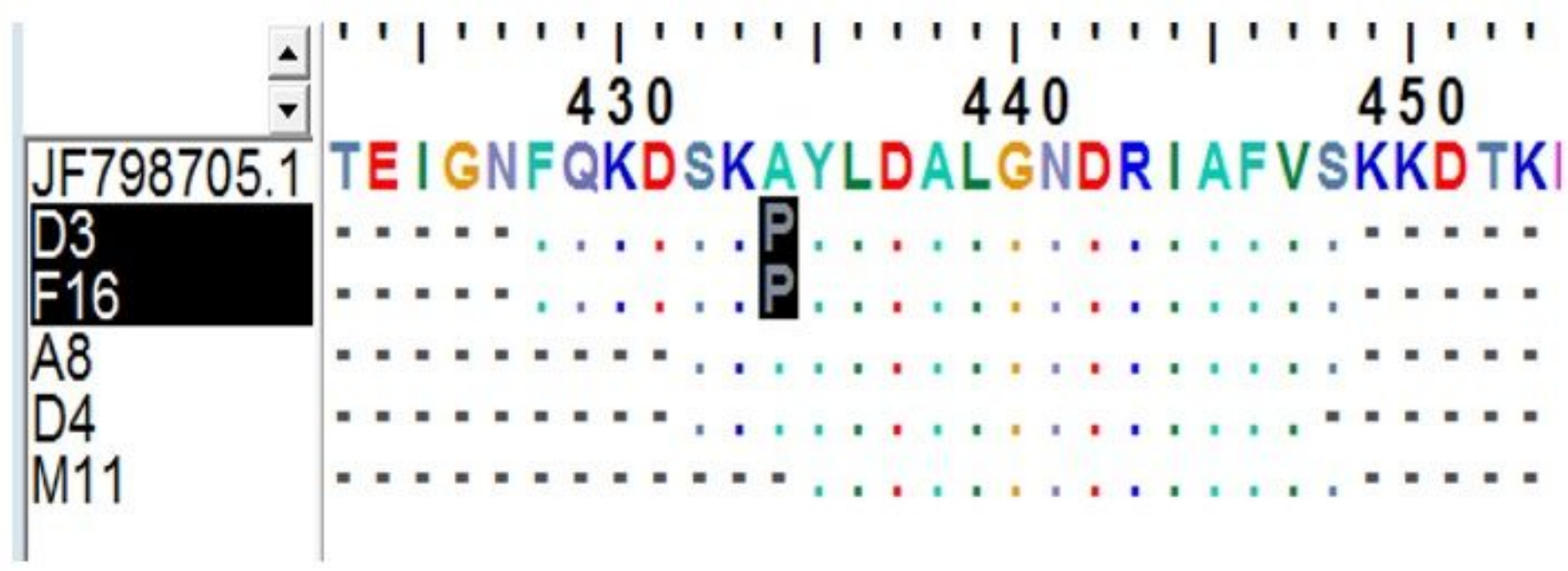

B

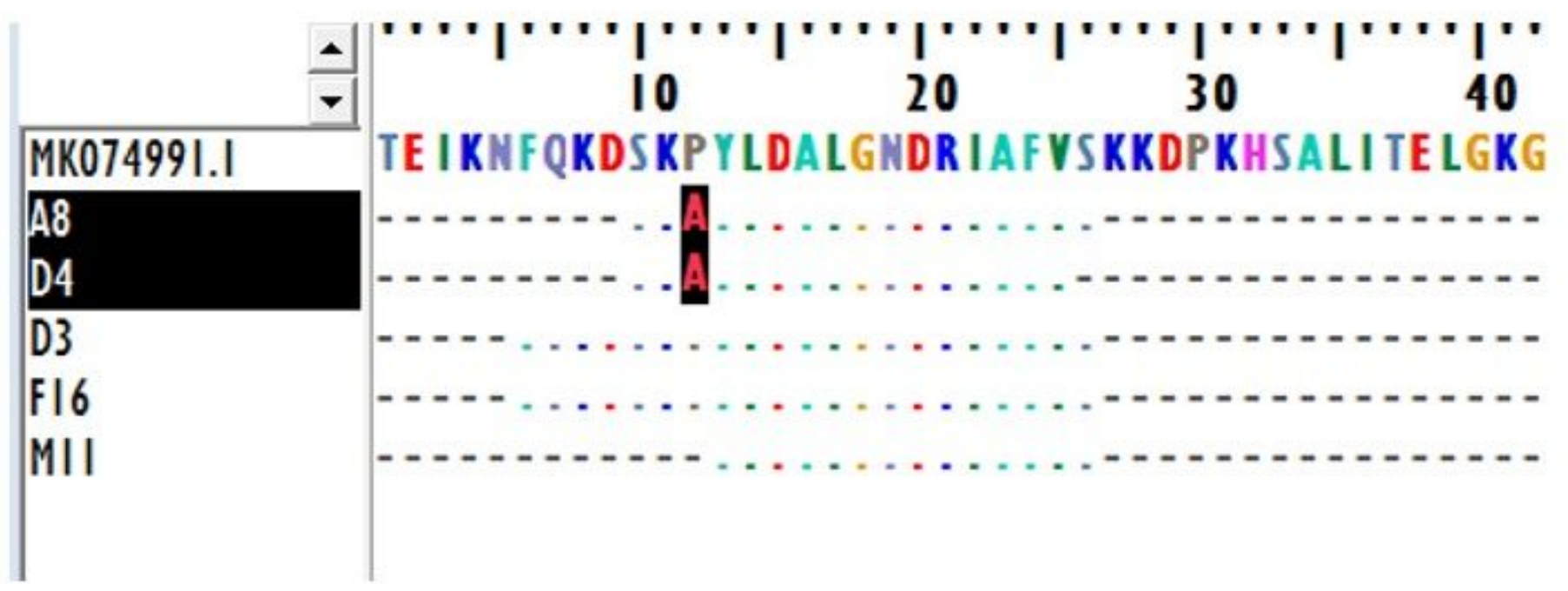

Figure 3

Alignment of cagA protein sequences with amino acid sequences of JF798705.1 reference sequence (A) and MK074991.1 reference sequence (B).

\section{Supplementary Files}

This is a list of supplementary files associated with this preprint. Click to download.

- FigureS1.docx 
- FigureS2.docx

Page 14/14 